\title{
EFFECT OF GLUTAMIC ACID AND BORON ON GROWTH AND PRODUCTIVITY OF RED GLOBE GRAPEVINES
}

Asmaa, A. Ibrahiem* and Radwan, E.M.A**

*Vitiulture Dept. Hort. Res. Instit. ARC, Giza, Egypt

** Hort. Dept. New Valley Fac. of Agric. Assiut Univ. Egypt

\section{ABSTRACT}

This study was carried out during 2015 and 2016 seasons to examine the effect of spraying glutamic acid at 100 to $400 \mathrm{ppm}$ and/or boric acid at 0.025 to $0.1 \%$ on growth aspects, vine nutritional status, yield, berries colouration\%, sunburned berries\% as well as physical and chemical characteristics of Red Globe grapes.

Subjecting the vines to glutamic acid at 100 to $400 \mathrm{ppm}$ and/or boric acid at 0.025 to $0.1 \%$ was very effective in enhancing main shoot length, leaf area, number of leaves/shoot, wood ripening coefficient, cane thickness, pruning wood weight, chlorophyll a \& b, total chlorophylls, $\mathrm{N}, \mathrm{P}, \mathrm{K}, \mathrm{Mg}$, yield, cluster weight and dimensions, berries colouration $\%$ and both physical and chemical characteristics, it is relative to the control treatment. Percentage of sunburned berries materially tended to reduce with the present treatments. Using glutamic acid was favourable than using boric acid in this respect. Combined application of glutamic acid and boric acid obviously surpassed the application of each alone in this respect.

The best results with regard to yield, berries colouration and quality of the berries were recorded on the vines that received three sprays (growth start, just after berry setting and one month later) of glutamic acid at $200 \mathrm{ppm}+$ boric acid at $0.05 \%$. Keywords: Red Globe grapevines, glutamic acid, boric acid, growth, yield, berries quality

\section{INTRODUCTION}

Red Globe grape cv grown under Minia region conditions suffered from uneven berries colouration and the sensitivity of the berries to sun-burn. For alleviating such two problems the idea of using boron and amino acids was sprouted.

Boron is favourable for enhancing berry setting, cluster weight and yield due to its striking promoting effect on enhancing fertilization, cell division, uptake of water and nutrients, the tolerance of fruit crops to infection with different disorders and biosynthesis pigments and building and translocation of sugars (Mengel $\boldsymbol{e t}$ al.,2001). Amino acids have an obvious promotion on the biosynthesis of proteins, plant pigments and natural hormones. They consider as an essential antioxidants help in protecting the plant cells from senescence through preventing the formation of free radicals (reactive oxygen species) (Davies, 1982).

Several workers emphasized the outstanding effect of using boron on growth, flowering, yield and fruit quality of grapevines (Abd El-Wahab, 2010; ElKady-Hanaa, 2011; Abdelaal et al., 2012; Akl et al., 2014 and Farahat, 2017).

Subjecting different grapevine cvs with amino acids had an announced promotion on growth, vine nutritional status, yield and fruit quality (Amin, 2007; Ahmed et al., 2007; Sayed-Heba, 2010; Ahmed et al., 2011; Abd El-aal, 2012; Mohamed, 2014 and Rekaby, 2017).

Fayoum J. Agric. Res. \& Dev., Vol. 33, No.1, January, 2019 
The merit of this study was examining the effect of spraying boron and glutamic acid on fruiting of Red Globe. The study focused on the effects of these treatments on counteracting the problems of irregular berries colouration and the incidence of sun-burned berries of Red Globe grown under Minia region conditions.

\section{MATERIALS AND METHODS}

This study was carried out during 2015 and 2016 seasons on 72 own - rooted 13 years old Red Globe grapevines located in a private vineyard located at Matay district, Minia Governorate. The selected vines are planted at $2 \times 3$ meters a part. Gable supporting system was followed. The selected vines were short pruned (spur pruning) during the $1^{\text {st }}$ week of Jan. during both seasons leaving 72 eyes(on the basis of 20 fruiting spurs $\mathrm{x}$ three eyes +6 replacement spurs x 2 eyes). The texture of tested soil is clay soil. Surface irrigation system was followed using Nile water. The vines received the common horticultural practices that already applied in the vineyard.

Soil analysis was done according to Wilde et al., (1985) and the obtained data are shown in Table (1).

Table (1): Analysis of the tested soil

\begin{tabular}{|l|c|}
\hline \multicolumn{1}{|c|}{ Content } & Value \\
\hline Sand \% & 6.1 \\
\hline Silt \% & 22.9 \\
\hline Clay \% & 71.0 \\
\hline Texture grade & Clay \\
\hline $\mathrm{pH}(1: 2.5$ extract $)$ & 7.69 \\
\hline EC $\left(1: 2.5\right.$ extract) $\left.\mathrm{dsm}^{-1}\right)$ & 0.70 \\
\hline Calcium carbonate \% & 1.25 \\
\hline O.M & 2.0 \\
\hline Total N\% & 0.09 \\
\hline Available P ( Olsen, ppm) & 4.1 \\
\hline Available K ( ammonium acetate , ppm) & 410 \\
\hline Available DTPA & - \\
\hline Zn & 1.9 \\
\hline Fe & 2.1 \\
\hline Mn & 1.7 \\
\hline
\end{tabular}

1. Control

The selected vines (72 vines) subjected to the following twelve treatments

2. Glutamic acid at $200 \mathrm{ppm}$

3. Glutamic acid at $400 \mathrm{ppm}$

4. Boric acid at $0.025 \%$

5. Boric acid at $0.05 \%$

6. Boric acid at $0.1 \%$

7. Glutamic acid at $200 \mathrm{ppm}+$ Boric acid at $0.025 \%$

8. Glutamic acid at $200 \mathrm{ppm}+$ Boric acid at $0.05 \%$

9. Glutamic acid at $200 \mathrm{ppm}+$ Boric acid at $0.1 \%$

10. Glutamic acid at $400 \mathrm{ppm}+$ Boric acid at $0.025 \%$

Fayoum J. Agric. Res. \& Dev., Vol. 33, No.1, January, 2019 
11. Glutamic acid at $400 \mathrm{ppm}+$ Boric acid at $0.05 \%$

12. Glutamic acid at $400 \mathrm{ppm}+$ Boric acid at $0.1 \%$

Each treatment was replicated three times, two vines per each. Boric acid (17\% B) and glutamic acid were sprayed three times at growth start (mid. of March), just after fruit setting (mid. April) and one month later (mid. May). Triton B as a wetting agent was used at $0.05 \%$ to the twelve treatments. Spraying was done till runoff. Randomized complete block design (RCBD) was followed in which the experiment included twelve treatments and each treatment was replicated three times, two vines per each.

During both seasons, the following parameters were recorded:

1- Vegetative growth criteria such as main shoot length $(\mathrm{cm})$, number of leaves/shoot, leaf area $(\mathrm{cm})^{2}$ (Ahmed and Morsy, 1999), wood ripening coefficient (Bouard, 1966), cane thickness $(\mathrm{cm})$ and pruning wood weight $(\mathrm{kg}) / \mathrm{vine}$.

2- Percentages of $\mathrm{N}, \mathrm{P}, \mathrm{K}$ and $\mathrm{Mg}$ (in dry weight basis) in the leaves (Cottenie $\boldsymbol{e t}$ al., 1982 and Balo et al., 1988).

3- Leaf photosynthesis pigments namely chlorophylls a \& b, total chlorophylls and total carotenoids (mg/1g F.W) (von-Wettstein, 1957).

4- Yield expressed in weight $(\mathrm{kg})$ and number of clusters/vine.

5- Weighty $(\mathrm{g})$, length and shoulder of cluster $(\mathrm{cm})$.

6- Percentages of berries colouration and sun-burned berries.

7- Physical and chemical characteristics of the berries namely berry weight $(\mathrm{g})$, T.S.S. \%, total acidity \% (as g tartaric acid/100 ml juice) (A.O.A.C., 2000) and total anthocyanins (mg/1 g F.W) (Fulcki and Francies, 1968).

Statistical analysis was done using randomized complete block design (RCBD) according to Mead $\boldsymbol{e t} \boldsymbol{a l}$. , (1993). Treatment means were compared using new L.S.D. at $5 \%$.

\section{RESULTS AND DISCUSSION}

\section{1- Vegetative growth characteristics:}

Data in Table (2) obviously reveal that spraying glutamic acid at 200 to 400 $\mathrm{ppm}$ and/or boric acid at 0.025 to $0.1 \%$ significantly was responsible for stimulating the six growth aspects namely main shoot length, number of leaves/shoot, leaf area, wood ripening coefficient, cane thickness and pruning wood weight relative to the control treatment. Using glutamic acid at 200 to $400 \mathrm{ppm}$ significantly was superior than using boric acid at 0.025 to $0.1 \%$ in stimulating these growth aspects. There was a gradual stimulation on these growth traits with increasing concentrations of glutamic acid and boric acid. Increasing concentrations of glutamic acid from 200 to $400 \mathrm{ppm}$ and boric acid from 0.05 to $0.1 \%$. Combined applications of glutamic acid at 200 to $400 \mathrm{ppm}$ and boric acid from 0.025 to $0.1 \%$ was significantly favourable than using each material alone. The maximum values of these growth aspects were recorded on the vines that treated three times with glutamic acid at $400 \mathrm{ppm}$ plus boric acid at $0.1 \%$. The lowest values were recorded on the untreated vines. These results were true during both seasons.

Fayoum J. Agric. Res. \& Dev., Vol. 33, No.1, January, 2019 
The beneficial effects of boron on enhancing cell division, building and translocations of sugars, biosynthesis of IAA and uptake of water and nutrients surely reflected on enhancing growth traits (Mengel et al., 2001). These results regarding the effect of boron on enhancing growth aspects of Red Globe grapevines are in agreement with those obtained by Abd El-Wahab, (2010); El-Kady-Hanaa, (2011); Abdelaal et al., (2012); Akl et al., (2014) and Farahat, (2017). The beneficial effects of glutamic acid on the biosynthesis of proteins, plant pigments and IAA as well as protecting plan cells from oxidation by reach oxygen species could explain the present results (Davies, 1982).

The promoting effect of glutamic acid on growth aspects of Red Globe grapevine cv was emphasized by the results of Amin, (2007); Ahmed et al., (2007); Sayed-Heba, (2010); Ahmed et al., (2011); Abd El-aal, (2012); Mohamed, (2014) and Rekaby, (2017).

2- Leaf chemical components:

It is evident from the data in Tables $(3 \& 4)$ that single and combined applications of glutamic acid at 200 to $400 \mathrm{ppm}$ and boric acid at 0.025 to $0.1 \%$ caused significant promotion on $\mathrm{N}, \mathrm{P}, \mathrm{K}, \mathrm{Mg}$, chlorophylls a \& b, total chlorophylls and total carotenoids relative to the control treatment. Glutamic acid application significantly surpassed the applications of boric acid in enhancing these nutrients and leaf photosynthetic pigments. There was a progressive promotion on these leaf chemical components with increasing concentrations of glutamic acid and boric acid. Increasing concentrations of glutamic acid from 200 to $400 \mathrm{ppm}$ and boric acid from 0.05 to $0.1 \%$ had meaningless stimulation on these leaf chemical components. Combined applications of glutamic acid and boric acid significantly were preferable than using each material alone in enhancing these nutrients and plant pigments. The maximum values of these leaf chemical components were recorded on the vines that received three sprays of a mixture of glutamic acid at $400 \mathrm{ppm}$ plus boric acid at 0.1 $\%$. The untreated vines produced the lowest values. Similar results were announced during both seasons.

The promoting effect of boron on uptake of water and nutrients as well as the biosynthesis of plant pigments could explain the present results (Mengel et al., 2001). These results regarding the effect of boron on enhancing growth aspects of Red Globe grapevines are in agreement with those obtained by Abd El-Wahab, (2010); El-Kady-Hanaa, (2011); Abdelaal et al., (2012); Akl et al., (2014) and Farahat, (2017). The beneficial effects of amino acids on the biosynthesis of plant pigments could explain the present results (Davies, 1982).

The promoting effect of glutamic acid on growth aspects of Red Globe grapevine cv was emphasized by the results of Amin, (2007); Ahmed et al., (2007); Sayed-Heba, (2010); Ahmed et al., (2011); Abd El-aal, (2012); Mohamed, (2014) and Rekaby, (2017).

3- Yield and cluster aspects:

Data in table (5) noticeably reveal that subjected Red Globe grapevines three times with glutamic acid at 200 to $400 \mathrm{ppm}$ and/or boric acid at 0.025 to $0.1 \%$ significant was accompanied with improving yield expressed in weight and number

Fayoum J. Agric. Res. \& Dev., Vol. 33, No.1, January, 2019 
EFFECT OF GLUTAMIC ACID AND BORON ON GROWTH................. 47

of clusters/vine as well as weight, length and shoulder of cluster over the control treatment. The promotion significantly was in proportional to the increase in concentrations of glutamic acid and boric acid. Increasing concentrations of glutamic acid from 200 to $400 \mathrm{ppm}$ and boric acid from 0.025 to 0.15 failed to show significant promotion on yield and cluster aspects. Yield/vine and cluster aspects were significantly improved in response to using glutamic acid than using boric acid. Combined application of glutamic acid and boric acid significantly was superior than using each material alone in improving yield and cluster aspects. From economical point of view, using glutamic acid at $200 \mathrm{ppm}$ besides boric said at 0.05 $\%$ gave the best results with regard to yield. In such promised treatment, yield / vine reached 19.1 and $22.9 \mathrm{~kg}$, while in the untreated vines it reached 16.9 and $17.0 \mathrm{~kg}$ during both seasons, respectively. The percentage of on the yield due to using the promise treatment (glutamic acid at $200 \mathrm{ppm}+$ boric acid at $0.05 \%$ ) over the control treatment reached $13.0 \& 34.7 \%$ during both seasons, respectively. These results were true during both seasons.

The beneficial effects of boron and glutamic acid on enhancing growth aspects and vine nutritional status surely reflected on improving cluster weight and dimensions, thereby the yield/vine.

These results regarding the effect of boron on enhancing growth aspects of Red Globe grapevines are in agreement with those obtained by Abd El-Wahab, (2010); El-Kady-Hanaa, (2011); Abdelaal et al., (2012); Akl et al., (2014) and Farahat, (2017). The beneficial effects of amino acids on the biosynthesis of plant pigments could explain the present results (Davies, 1982).

The promoting effect of glutamic acid on growth aspects of Red Globe grapevine cv was emphasized by the results of Amin, (2007); Ahmed et al., (2007); Sayed-Heba, (2010); Ahmed et al., (2011); Abd El-aal, (2012); Mohamed, (2014) and Rekaby, (2017).

\section{4- Percentages of berries colouration:}

Percentage of berries colouration as shown in Table (6) significantly was improved in response to treating the vines with glutamic acid at 200 to $400 \mathrm{ppm}$ and/or boric acid at 0.025 to $0.1 \%$ relative to the control. Using glutamic acid at 200 to $400 \mathrm{ppm}$ significantly was superior than using boric acid at 0.025 to $0.1 \%$ in enhancing berries colouration. Increasing concentrations of glutamic acid and boric acid caused a gradual promotion on berries colouration. Increasing concentrations of glutamic acid from 200 to $400 \mathrm{ppm}$ and boric acid from 0.025 to $0.1 \%$ had no significant promotion on berries colouration. Combined application of glutamic acid and boric acid significantly surpassed the application of each material alone in enhancing berries colouration. From economical point view, the best colouration of berries was occurred when the vines treated three times with a mixture of glutamic acid at $200 \mathrm{ppm}+$ boric acid at $0.05 \%$ under such promised treatment berries colouration \% reached 81.5 and $83.0 \%$. While in the untreated vines reached 67.6 and $66.7 \%$ during both seasons, respectively. The percentage of increment on berries colouration $\%$ due to use the promised treating over the control treatment

Fayoum J. Agric. Res. \& Dev., Vol. 33, No.1, January, 2019 
Asmaa, A. Ibrahiem* and Radwan, E.M.A**

reached 20.6 and $24.4 \%$ during both seasons, respectively. These results were true during both seasons.

The beneficial effects of glutamic acid and boric acid on enhancing plant pigments and the biosynthesis of sugars could explain the present results (Davies, 1982 and Mengel et al., 2001).

These results regarding the effect of boron on enhancing growth aspects of Red Globe grapevines are in agreement with those obtained by Abd El-Wahab, (2010); El-Kady-Hanaa, (2011); Abdelaal et al., (2012); Akl et al., (2014) and Farahat, (2017). The beneficial effects of amino acids on the biosynthesis of plant pigments could explain the present results (Davies, 1982).

The promoting effect of glutamic acid on growth aspects of Red Globe grapevine cv was emphasized by the results of Amin, (2007); Ahmed et al., (2007); Sayed-Heba, (2010); Ahmed et al., (2011); Abd El-aal, (2012); Mohamed, (2014) and Rekaby, (2017). 
EFFECT OF GLUTAMIC ACID AND BORON ON GROWTH.................. 49 Table (2): Effect of single and combined applications of glutamic acid and boric acid on some vegetative growth aspects of Red Globe grapevines during 2015 and 2016 seasons

\begin{tabular}{|c|c|c|c|c|c|c|c|c|c|c|c|c|}
\hline \multirow[t]{2}{*}{ Treatment } & \multicolumn{2}{|c|}{$\begin{array}{l}\text { Main shoot } \\
\text { length }(\mathrm{cm} .)\end{array}$} & \multicolumn{2}{|c|}{$\begin{array}{c}\text { No. of } \\
\text { leaves/shoot }\end{array}$} & \multicolumn{2}{|c|}{$\begin{array}{l}\text { Leaf area } \\
\quad(\mathrm{cm} .)\end{array}$} & \multicolumn{2}{|c|}{$\begin{array}{c}\text { Wood } \\
\text { ripening } \\
\text { coefficient }\end{array}$} & \multicolumn{2}{|c|}{$\begin{array}{c}\text { Cane } \\
\text { thickness } \\
(\mathbf{m m})\end{array}$} & \multicolumn{2}{|c|}{$\begin{array}{c}\text { Pruning wood } \\
\text { weight/vine } \\
(\mathrm{kg})\end{array}$} \\
\hline & 2015 & 2016 & 2015 & 2016 & 2015 & 2016 & 2015 & 2016 & 2015 & 2016 & 2015 & 2016 \\
\hline Control & 130.1 & 131.3 & 15.0 & 16.0 & 121.0 & 122.0 & 0.69 & 0.71 & 0.74 & 0.76 & 1.41 & 1.42 \\
\hline Glutamic acid at $200 \mathrm{ppm}$ & 136.0 & 136.9 & 18.0 & 19.0 & 128.0 & 128.7 & 0.86 & 0.86 & 1.11 & 1.15 & 1.80 & 1.78 \\
\hline Glutamic acid at $400 \mathrm{ppm}$ & 136.4 & 136.4 & 18.0 & 19.0 & 128.3 & 129.0 & 0.87 & 0.87 & 1.12 & 1.16 & 1.81 & 1.79 \\
\hline Boric acid at $0.025 \%$ & 132.3 & 133.3 & 16.0 & 17.0 & 123.0 & 123.8 & 0.74 & 0.74 & 0.85 & 0.89 & 1.52 & 1.50 \\
\hline Boric acid at $0.05 \%$ & 134.0 & 135.3 & 17.0 & 18.0 & 125.0 & 125.7 & 0.79 & 0.79 & 0.95 & 1.02 & 1.64 & 1.61 \\
\hline Boric acid at $0.1 \%$ & 134.3 & 135.3 & 17.0 & 18.0 & 125.3 & 126.0 & 0.80 & 0.81 & 0.96 & 1.03 & 1.65 & 1.62 \\
\hline $\begin{array}{l}\text { Glutamic acid at } 200 \mathrm{ppm}+ \\
\text { Boric acid at } 0.025 \%\end{array}$ & 139.0 & 140.0 & 20.0 & 21.0 & 130.0 & 130.8 & 0.90 & 0.91 & 1.29 & 1.35 & 1.91 & 1.89 \\
\hline $\begin{array}{c}\text { Glutamic acid at } 200 \mathrm{ppm}+ \\
\text { Boric acid at } 0.05 \%\end{array}$ & 141.0 & 141.9 & 22.0 & 23.0 & 132.0 & 133.0 & 0.95 & 0.95 & 1.45 & 1.50 & 2.11 & 1.99 \\
\hline $\begin{array}{c}\text { Glutamic acid at } 200 \mathrm{ppm}+ \\
\text { Boric acid at } 0.1 \% \\
\end{array}$ & 141.3 & 142.0 & 23.0 & 23.0 & 132.3 & 133.3 & 0.96 & 0.96 & 1.46 & 1.51 & 2.12 & 2.00 \\
\hline $\begin{array}{c}\text { Glutamic acid at } 400 \mathrm{ppm}+ \\
\text { Boric acid at } 0.025 \%\end{array}$ & 139.3 & 140.1 & 20.0 & 21.0 & 130.1 & 131.1 & 0.90 & 0.91 & 1.30 & 1.36 & 1.92 & 1.90 \\
\hline $\begin{array}{c}\text { Glutamic acid at } 400 \mathrm{ppm}+ \\
\text { Boric acid at } 0.05 \%\end{array}$ & 141.2 & 142.0 & 22.0 & 23.0 & 132.3 & 133.3 & 0.95 & 0.95 & 1.46 & 1.51 & 2.12 & 2.00 \\
\hline $\begin{array}{c}\text { Glutamic acid at } 400 \mathrm{ppm}+ \\
\text { Boric acid at } 0.1 \%\end{array}$ & 141.4 & 142.3 & 23.0 & 23.0 & 132.5 & 133.5 & 0.96 & 0.96 & 1.47 & 1.52 & 2.13 & 2.01 \\
\hline New L.S.D. at 5\% & 1.4 & 1.3 & 1.0 & 1.0 & 1.4 & 1.6 & 0.04 & 0.05 & 0.09 & 0.10 & 0.08 & 0.06 \\
\hline
\end{tabular}

Table (3): Effect of single and combined applications of glutaimc acid and boric acid on the percentages of $\mathrm{N}, \mathrm{P}, \mathrm{K}$ and $\mathrm{Mg}$ in the leaves of Red Globe grapevines during 2015 and 2016 seasons

\begin{tabular}{|c|c|c|c|c|c|c|c|c|}
\hline \multirow{2}{*}{ Treatment } & \multicolumn{2}{|c|}{ Leaf N \% } & \multicolumn{2}{|c|}{ Leaf P \% } & \multicolumn{2}{|c|}{ Leaf K \% } & \multicolumn{2}{|c|}{ Leaf Mg \% } \\
\hline & 2015 & 2016 & 2015 & 2016 & 2015 & 2016 & 2015 & 2016 \\
\hline Control & 1.59 & 1.62 & 0.114 & 0.116 & 1.11 & 1.14 & 0.50 & 0.49 \\
\hline Glutamic acid at $200 \mathrm{ppm}$ & 1.91 & 1.96 & 0.161 & 0.167 & 1.36 & 1.40 & 0.72 & 0.75 \\
\hline Glutamic acid at $400 \mathrm{ppm}$ & 1.92 & 1.97 & 0.160 & 0.167 & 1.37 & 1.41 & 0.73 & 0.76 \\
\hline Boric acid at $0.025 \%$ & 1.69 & 1.74 & 0.129 & 0.136 & 1.18 & 1.25 & 0.56 & 0.60 \\
\hline Boric acid at $0.05 \%$ & 1.80 & 1.86 & 0.144 & 0.150 & 1.26 & 1.36 & 0.63 & 0.68 \\
\hline Boric acid at $0.1 \%$ & 1.81 & 1.88 & 0.145 & 0.151 & 1.27 & 1.37 & 0.64 & 0.69 \\
\hline Glutamic acid at $200 \mathrm{ppm}+$ Boric acid at $0.025 \%$ & 2.01 & 2.07 & 0.171 & 0.181 & 1.45 & 1.47 & 0.80 & 0.84 \\
\hline Glutamic acid at $200 \mathrm{ppm}+$ Boric acid at $0.05 \%$ & 2.11 & 2.18 & 0.181 & 0.194 & 1.55 & 1.58 & 0.86 & 0.91 \\
\hline Glutamic acid at $200 \mathrm{ppm}+$ Boric acid at $0.1 \%$ & 2.12 & 2.19 & 0.182 & 0.195 & 1.56 & 1.59 & 0.87 & 0.92 \\
\hline Glutamic acid at $400 \mathrm{ppm}+$ Boric acid at $0.025 \%$ & 2.02 & 2.08 & 0.172 & 0.182 & 1.46 & 1.48 & 0.81 & 0.85 \\
\hline Glutamic acid at $400 \mathrm{ppm}+$ Boric acid at $0.05 \%$ & 2.12 & 2.19 & 0.183 & 0.195 & 1.56 & 1.59 & 0.87 & 0.92 \\
\hline Glutamic acid at $400 \mathrm{ppm}+$ Boric acid at $0.1 \%$ & 2.13 & 2.20 & 0.184 & 0.196 & 1.57 & 1.60 & 0.88 & 0.93 \\
\hline New L.S.D. at 5\% & 0.06 & $\mathbf{0 . 0 5}$ & $\mathbf{0 . 0 1 0}$ & 0.011 & 0.04 & $\mathbf{0 . 0 3}$ & $\mathbf{0 . 0 3}$ & $\mathbf{0 . 0 3}$ \\
\hline
\end{tabular}

Fayoum J. Agric. Res. \& Dev., Vol. 33, No.1, January, 2019 
Asmaa, A. Ibrahiem* and Radwan, E.M.A**

Table (4): Effect of single and combined applications of glutathione and boric acid on some leaf pigments of Red Globe grapevines during 2015 and 2016 seasons

\begin{tabular}{|c|c|c|c|c|c|c|c|c|}
\hline \multirow[t]{2}{*}{ Treatment } & \multicolumn{2}{|c|}{$\begin{array}{c}\text { Chlorophyll a } \\
\text { (mg/g F.W) }\end{array}$} & \multicolumn{2}{|c|}{$\begin{array}{c}\text { Chlorophyll b } \\
\text { (mg/g F.W) }\end{array}$} & \multicolumn{2}{|c|}{$\begin{array}{c}\text { Total } \\
\text { chlorophylls } \\
(\mathrm{mg} / \mathrm{g} \text { F.W })\end{array}$} & \multicolumn{2}{|c|}{$\begin{array}{c}\text { Total } \\
\text { carotenoids } \\
(\mathrm{mg} / \mathrm{g} \text { F.W })\end{array}$} \\
\hline & 2015 & 2016 & 2015 & 2016 & 2015 & 2016 & 2015 & 2016 \\
\hline Control & 3.15 & 3.20 & 1.11 & 1.14 & 4.26 & 4.34 & 1.04 & 1.03 \\
\hline Glutamic acid at $200 \mathrm{ppm}$ & 3.15 & 3.55 & 1.36 & 1.40 & 4.86 & 4.95 & 1.25 & 1.24 \\
\hline Glutamic acid at $400 \mathrm{ppm}$ & 3.51 & 3.56 & 1.37 & 1.41 & 4.88 & 4.97 & 1.26 & 1.25 \\
\hline Boric acid at $0.025 \%$ & 3.24 & 3.30 & 1.17 & 1.22 & 4.41 & 4.52 & 1.10 & 1.09 \\
\hline Boric acid at $0.05 \%$ & 3.34 & 3.40 & 1.25 & 1.29 & 4.59 & 4.69 & 1.16 & 1.15 \\
\hline Boric acid at $0.1 \%$ & 3.35 & 3.41 & 1.26 & 1.30 & 4.61 & 4.71 & 1.17 & 1.18 \\
\hline Glutamic acid at $200 \mathrm{ppm}+$ Boric acid at $0.025 \%$ & 3.64 & 3.70 & 1.45 & 1.52 & 5.09 & 5.22 & 1.34 & 1.35 \\
\hline Glutamic acid at $200 \mathrm{ppm}+$ Boric acid at $0.05 \%$ & 3.74 & 3.80 & 1.55 & 1.61 & 5.29 & 5.41 & 1.41 & 1.42 \\
\hline Glutamic acid at $200 \mathrm{ppm}+$ Boric acid at $0.1 \%$ & 3.75 & 3.81 & 1.56 & 1.62 & 5.31 & 5.43 & 1.42 & 1.43 \\
\hline Glutamic acid at $400 \mathrm{ppm}+$ Boric acid at $0.025 \%$ & 3.65 & 3.71 & 1.46 & 1.53 & 5.11 & 5.24 & 1.35 & 1.36 \\
\hline Glutamic acid at $400 \mathrm{ppm}+$ Boric acid at $0.05 \%$ & 3.75 & 3.81 & 1.56 & 1.62 & 5.31 & 5.42 & 1.42 & 1.43 \\
\hline Glutamic acid at $400 \mathrm{ppm}+$ Boric acid at $0.1 \%$ & 3.76 & 3.82 & 1.57 & 1.63 & 5.33 & 5.45 & 1.43 & 1.44 \\
\hline New L.S.D. at 5\% & $\mathbf{0 . 0 5}$ & 0.06 & 0.04 & $\mathbf{0 . 0 3}$ & 0.06 & $\mathbf{0 . 0 7}$ & $\mathbf{0 . 0 3}$ & 0.02 \\
\hline
\end{tabular}

\section{5-Percentage of dun-burned berries:}

Data in table (6) clearly show that percentage of sun-burned berries significantly declined with using glutamic acid at 200 to $400 \mathrm{ppm}$ and/or boric acid at 0.025 to $0.1 \%$ relative to the control. The reduction on the percentage of sunburned berries significantly was correlated with increasing concentrations of glutamic acid and boric acid. Meaningless reduction on sun-burned berries \% was observed among the higher two concentrations of glutamic acid and boric acid.

Using glutamic acid significantly was favourable than using boric acid in reducing. Using both materials together significantly gave the lowest values of the application of each material alone. The lowest values of sun-burned berries from economical of point view, $(8.0 \& 7.0 \%)$ were recorded on the vines that received three sprays of glutamic acid at $200 \mathrm{ppm}+$ boric acid at $0.05 \%$, while percentage of sun-burned berries reached $19.9 \& 20.0 \%$ in the control vines, during both seasons, respectively. These results were true during both seasons.

The effect of boron in enhancing the tolerance of the plants to disorders and facilitating water uptake (Mengel $\boldsymbol{e t}$ al., 2001) as well as the effect of glutamic acid as ant oxidative on enhancing the tolerance to abiotic stress could be explain the present results (Davies, 1982).

These results regarding the effect of boron on enhancing growth aspects of Red Globe grapevines are in agreement with those obtained by Abd El-Wahab, (2010); El-Kady-Hanaa, (2011); Abdelaal et al., (2012); Akl et al., (2014) and Farahat, (2017). The beneficial effects of amino acids on the biosynthesis of plant pigments could explain the present results (Davies, 1982).

The promoting effect of glutamic acid on growth aspects of Red Globe grapevine cv was emphasized by the results of Amin, (2007); Ahmed et al., (2007); Sayed-Heba, (2010); Ahmed et al., (2011); Abd El-aal, (2012); Mohamed, (2014) and Rekaby, (2017).

\section{6-Physical and chemical characteristics:}

Data in table (6) clearly show carrying out three sprays of glutamic acid at 200 to $400 \mathrm{ppm}$ and/or boric acid at 0.025 to $0.1 \%$ significantly was very effective

Fayoum J. Agric. Res. \& Dev., Vol. 33, No.1, January, 2019 
EFFECT OF GLUTAMIC ACID AND BORON ON GROWTH................ 51 in improving quality of the berries in terms of increasing berry weight, T.S.S. \%, and total anthocyanins and reducing total acidity $\%$ relative to the control. The promotion was significantly correlated with using glutamic acid relative to the application of boric acid as well as with increasing concentrations of glutamic acid and boric acid concentrations. Increasing concentrations of glutamic acid from 200 to 400 and boric acid at 0.05 to $0.1 \%$ failed to show significantly promotion on quality in the vines that received both materials together than using each material alone. The best results were obtained due to using glutamic acid at $200 \mathrm{ppm}+$ boric acid at $0.05 \%$. Similar trend was noticed during both seasons.

The effect of boron and glutamic acid on enhancing the biosynthesis of pigments and sugars surely reflected on enhancing fruit quality (Davies, 1982 and Mengel et al., 2001).

These results regarding the effect of boron on enhancing growth aspects of Red Globe grapevines are in agreement with those obtained by Abd El-Wahab, (2010); El-Kady-Hanaa, (2011); Abdelaal et al., (2012); Akl et al., (2014) and Farahat, (2017). The beneficial effects of amino acids on the biosynthesis of plant pigments could explain the present results (Davies, 1982).

The promoting effect of glutamic acid on growth aspects of Red Globe grapevine cv was emphasized by the results of Amin, (2007); Ahmed et al., (2007); Sayed-Heba, (2010); Ahmed et al., (2011); Abd El-aal, (2012); Mohamed, (2014) and Rekaby, (2017).

Table (5): Effect of single and combined applications of glutathione and boric acid on the yield, average cluster weight and dimensions of Red Globe grapevines during 2015 and 2016 seasons

\begin{tabular}{|c|c|c|c|c|c|c|c|c|c|c|}
\hline \multirow[t]{2}{*}{ Treatment } & \multicolumn{2}{|c|}{$\begin{array}{c}\text { No. of } \\
\text { clusters/vine }\end{array}$} & \multicolumn{2}{|c|}{$\begin{array}{c}\text { Yield/vine } \\
\text { (kg) }\end{array}$} & \multicolumn{2}{|c|}{$\begin{array}{l}\text { Av. Cluster } \\
\text { weight (g) }\end{array}$} & \multicolumn{2}{|c|}{$\begin{array}{l}\text { Av. Cluster } \\
\text { length (cm) }\end{array}$} & \multicolumn{2}{|c|}{$\begin{array}{c}\text { Av. Cluster } \\
\text { shoulder (cm) }\end{array}$} \\
\hline & 2016 & 2017 & 2016 & 2017 & 2016 & 2017 & 2016 & 2017 & 2016 & 2017 \\
\hline Control & 24.0 & 24.0 & 16.9 & 17.0 & 705.0 & 707.0 & 25.0 & 24.1 & 10.1 & 10.2 \\
\hline Glutamic acid at $200 \mathrm{ppm}$ & 24.0 & 28.0 & 17.8 & 20.8 & 740.0 & 741.0 & 26.2 & 25.5 & 11.0 & 11.1 \\
\hline Glutamic acid at $400 \mathrm{ppm}$ & 24.0 & 28.0 & 17.9 & 20.8 & 741.0 & 741.5 & 26.3 & 25.6 & 11.1 & 11.2 \\
\hline Boric acid at $0.025 \%$ & 24.0 & 25.0 & 17.2 & 17.9 & 715.0 & 717.0 & 25.3 & 24.5 & 10.4 & 10.5 \\
\hline Boric acid at $0.05 \%$ & 24.0 & 26.0 & 17.4 & 18.9 & 725.0 & 726.0 & 25.6 & 24.9 & 10.5 & 10.6 \\
\hline Boric acid at $0.1 \%$ & 24.0 & 26.0 & 17.4 & 18.9 & 726.0 & 726.0 & 25.7 & 25.0 & 11.6 & 10.7 \\
\hline Glutamic acid at200ppm+Boric acid at $0.025 \%$ & 24.0 & 29.0 & 18.0 & 21.8 & 751.0 & 752.0 & 27.0 & 26.1 & 12.1 & 12.2 \\
\hline Glutamic acid at $200 \mathrm{ppm}+$ Boric acid at $0.05 \%$ & 25.0 & 30.0 & 19.1 & 22.9 & 762.0 & 763.0 & 27.5 & 27.3 & 12.5 & 12.6 \\
\hline Glutamic acid at $200 \mathrm{ppm}+$ Boric acid at $0.1 \%$ & 25.0 & 30.0 & 19.1 & 22.9 & 763.0 & 763.0 & 27.6 & 27.4 & 12.6 & 12.7 \\
\hline Glutamic acid at $400 \mathrm{ppm}+$ Boric acid at $0.025 \%$ & 24.0 & 29.0 & 18.0 & 21.9 & 751.0 & 752.0 & 27.1 & 26.2 & 12.2 & 12.3 \\
\hline Glutamic acid at $400 \mathrm{ppm}+$ Boric acid at $0.05 \%$ & 25.0 & 30.0 & 19.1 & 22.9 & 762.5 & 763.0 & 27.6 & 27.4 & 12.5 & 12.7 \\
\hline Glutamic acid at $400 \mathrm{ppm}+$ Boric acid at $0.1 \%$ & 25.0 & 30.0 & 19.8 & 22.9 & 763.0 & 763.0 & 27.6 & 27.5 & 12.8 & 12.8 \\
\hline New L.S.D. at $5 \%$ & NS & 1.0 & 0.3 & 0.5 & 8.1 & 8.7 & 0.2 & 0.3 & 0.2 & 0.2 \\
\hline
\end{tabular}

Fayoum J. Agric. Res. \& Dev., Vol. 33, No.1, January, 2019 
Table (6): Effect of single and combined applications of glutathione and boric acid on percentages of berries colouration and sunburned berries and some chemical characteristics of the berries of Red Globe grapevines during 2015 and 2016 seasons

\begin{tabular}{|c|c|c|c|c|c|c|c|c|c|c|c|c|}
\hline \multirow[t]{2}{*}{ Treatment } & \multicolumn{2}{|c|}{$\begin{array}{c}\text { Berries } \\
\text { colouration } \\
\%\end{array}$} & \multicolumn{2}{|c|}{$\begin{array}{l}\text { Sunberries } \\
\text { berry } \%\end{array}$} & \multicolumn{2}{|c|}{$\begin{array}{c}\text { Berry } \\
\text { weight }(g)\end{array}$} & \multicolumn{2}{|c|}{ T.S.S. \% } & \multicolumn{2}{|c|}{$\begin{array}{c}\text { Total } \\
\text { acidity } \%\end{array}$} & \multicolumn{2}{|c|}{$\begin{array}{c}\text { Total } \\
\text { anthocyanins } \\
(\mathrm{mg} / 1.0 \mathrm{~g} \\
\text { F.W })\end{array}$} \\
\hline & 2015 & 2016 & 2015 & 2016 & 2015 & 2016 & 2015 & 2016 & 2015 & 2016 & 2015 & 2016 \\
\hline Control & 67.6 & 66.7 & 19.9 & 20.0 & 10.1 & 10.3 & 17.0 & 17.2 & 0.681 & 0.683 & 24.1 & 23.9 \\
\hline Glutamic acid at $200 \mathrm{ppm}$ & 75.9 & 77.0 & 12.0 & 11.9 & 11.9 & 12.0 & 19.0 & 19.2 & 0.620 & 0.621 & 27.3 & 28.0 \\
\hline Glutamic acid at $400 \mathrm{ppm}$ & 76.0 & 77.1 & 11.9 & 11.9 & 12.0 & 12.0 & 14.1 & 14.3 & 0.619 & 0.620 & 27.4 & 28.1 \\
\hline Boric acid at $0.025 \%$ & 70.0 & 71.1 & 15.0 & 14.8 & 10.6 & 10.7 & 17.6 & 17.8 & 0.661 & 0.662 & 25.1 & 25.8 \\
\hline Boric acid at $0.05 \%$ & 72.5 & 73.6 & 13.5 & 13.3 & 11.1 & 11.2 & 18.2 & 18.3 & 0.641 & 0.641 & 26.1 & 26.8 \\
\hline Boric acid at $0.1 \%$ & 72.6 & 73.7 & 13.4 & 13.2 & 11.2 & 11.3 & 18.3 & 18.4 & 0.640 & 0.640 & 26.2 & 26.9 \\
\hline $\begin{array}{c}\text { Glutamic acid at } 200 \mathrm{ppm}+\text { Boric } \\
\text { acid at } 0.025 \%\end{array}$ & 79.0 & 80.2 & 10.0 & 9.9 & 12.6 & 12.8 & 19.9 & 21.1 & 0.601 & 0.601 & 28.9 & 29.6 \\
\hline $\begin{array}{c}\text { Glutamic acid at } 200 \mathrm{ppm}+\text { Boric } \\
\text { acid at } 0.05 \%\end{array}$ & 81.5 & 83.0 & 8.0 & 7.9 & 13.1 & 13.3 & 20.6 & 20.7 & 0.580 & 0.579 & 30.0 & 31.0 \\
\hline $\begin{array}{c}\text { Glutamic acid at } 200 \mathrm{ppm}+\text { Boric } \\
\text { acid at } 0.1 \% \\
\end{array}$ & 81.6 & 83.1 & 7.9 & 7.8 & 13.2 & 13.4 & 20.6 & 20.8 & 0.579 & 0.578 & 30.1 & 31.1 \\
\hline $\begin{array}{c}\text { Glutamic acid at } 400 \mathrm{ppm}+\text { Boric } \\
\text { acid at } 0.025 \%\end{array}$ & 79.5 & 80.3 & 9.9 & 9.7 & 12.7 & 12.9 & 20.0 & 21.2 & 0.600 & 0.600 & 29.0 & 29.7 \\
\hline $\begin{array}{c}\text { Glutamic acid at } 400 \mathrm{ppm}+\text { Boric } \\
\text { acid at } 0.05 \%\end{array}$ & 81.6 & 83.1 & 7.9 & 7.7 & 13.2 & 13.4 & 20.6 & 20.8 & 0.579 & 0.577 & 30.0 & 31.1 \\
\hline $\begin{array}{c}\text { Glutamic acid at } 400 \mathrm{ppm}+\text { Boric } \\
\text { acid at } 0.1 \%\end{array}$ & 81.8 & 83.2 & 7.8 & 7.5 & 13.3 & 13.0 & 20.6 & 20.9 & 0.578 & 0.573 & 30.2 & 31.2 \\
\hline New L.S.D. at 5\% & 1.1 & 1.2 & 1.3 & 1.0 & 0.4 & 0.5 & 0.5 & 0.5 & 0.015 & 0.014 & 0.6 & 0.7 \\
\hline
\end{tabular}

\section{REFERENCES}

Abd El-aal, E.E.H.A. (2012): The synergistic effects of using some nutrients as well as antioxidant substances on growth, nutritional status and productivity of Thompson seedless grapevines grown under Sohag region. Ph. D. Thesis Fac. of Agric. Sohag Univ. Egypt.

Abd El-Wahab, M.H., (2010): Relation of fruiting in Superior grapevines with spraying sulphur, magnesium, zinc and boron. M. Sc. Thesis, Fac. of. Agric., Minia Univ. Egypt.

Abdelaal, A. H. M.; Abada, M. A. M. and Abd El-Rahman, M. A. Kh (2017): Response of Flame seedless grapevines to spraying boron and moringa extract. Proc. Of $7^{\text {th }}$ Inter. Conf. for Sustainable Agric. Develop. 6-8 March $1-14$.

Ahmed, F. F.; Mohamed, M. A. Abd El- Aal, A. M. K. and Amin, M. M. (2007); Response of Red Roomy grapevines, to application of amino acids and some micronutrients. The third Conf. of Sustain. Agric. and Develop. Fac. of Agric. Fayoum Univ. 12-14 Nov. pp. 150 - 170.

Ahmed, F.F. and Morsy, M.H. (1999): A new method for measuring leaf area in different fruit species. Minia J. of Agric. Res. 8 Develop., Vol. (19)pp. 97105.

Fayoum J. Agric. Res. \& Dev., Vol. 33, No.1, January, 2019 
EFFECT OF GLUTAMIC ACID AND BORON ON GROWTH................. 53

Akl, A.M.M.A.; Abdelaziz, F.H.; El- Sayed, M.A. and Mohamed, T.M.M. (2014): Response of Superior grapevines to spraying salicylic and boric acids. World Rural Observations. 6(4): 1-5.

Amin, M.M.A. (2007): Response of Red Roomy grapevines to application of amino acids and some micronutrients thesis Fac. of Agric. Minia Univ. Egypt.

Association of Official Agricultural Chemists (2000): Official Methods of Analysis (A.O.A.C), $12^{\text {th }}$ Ed. Benjamin Franklin Station, Washington D.C. U.S.A. pp. 490 - 510.

Balo, E.; Prilesszky, G.; Happ, I.; Kaholami, M, and Vega. L. (1988): Soil improvement and the use of leaf analysis for forecasting nutrient requirements of grapes. Potash Review (Subject 9, $2^{\text {nd }}$ suite, No. 61:1-5).

Bouard, J. (1966): Recharches, physiologiques sur la vigen at en particulier sur laoudment des serments. Thesis Sci. Nat. Bardeux France, p.34.

Cottenie, A.; Verloo, M.; Velghe, M. and Camerlynck, R. (1982): Chemical Analysis of Plant and Soil. Ghent, Belgium, Laboratory of Analytical and Agro- chemistry. State Univ. pp. 200-210.

Davies, D. D. (1982). Physiological aspects of protein turnover. In Nucleic Acids and Proteins in Plants I (pp. 189-228). Springer Berlin Heidelberg.

El- Kady-Hanaa, F.M. (2011): Productive performance of Thompson seedless grapevines in relation to application of some antioxidants, magnesium and boron. M. Sc. Thesis Fac. of Agric. Minia Univ. Egypt.

Farahat, I.A.M. (2017): Studies on pruning and fertilization of early and sweet grapevines growing under Minia Region condition. Ph.D. Thesis Fac. of Agric. Minia Univ., Egypt.

Fulcki, T. and Francis, F.J. (1968): Quantitative methods for anthocyanins II Determination of total anthocyanins and degradative index for berry juice J. Food Sci. 33: 78-83.

Lane, J H. and Eynon, L. (1965): Determination of reducing sugars by means of Fehlings solution with methylene blue as indicator. A.O.A.C Washington D.C. U.S.A.

Mead, R.; Cunjow, R.N. and Harted, A.M. (1993): Statistical Methods in Agricultural and Experimental Biology. Second Ed. Chapman \& Hall. London, pp. 10- 44.

Mengel, K.E.; Kirkbt, A.; Koesgarten, H. and Appel. T. (2001): principles of plant nutrition $5^{\text {th }}$ El- Kluwer Academic publishers, Dordrecht p. 1-311.

Mohamed, T.M.M. ( 2014 ). Relation of fruiting in Superior grapevines with spraying salicylic acids and boron. M. Sc. Thesis Fac. of Agric. Minia Univ. Egypt.

Rekaby, A.H.A. (2017): Effect of humic and fulvic acids, EM and some amino avids on growth vine nutritional status and fruiting of Flame seedless grapevines. M.Sc. Thesis Fac. of Agric. Al-Azhar Univ., Egypt.

Sayed-Heba, F.L. (2010): Effect of stimulant amino quaint- $\mathrm{Ca}$ and Zinc on yield and berries quality of Thomson seedless grapevines. M.Sc. Thesis Fac. of Agric. Minia Univ. Egypt.

Fayoum J. Agric. Res. \& Dev., Vol. 33, No.1, January, 2019 
Von-Wettstein, D. V. (1957): Chlorophyll- Lethale under submikroshopische formilkechrel der plastiden celi, prp. Trop. Res. Amer. Soc. Hort. Sci. 20 pp. $427-433$.

Wilde, S.A.; Corey, R.B.; Iyer J.G. and Voigt, G.K. (1985): Soil and Plant Analysis for Tree Culture. Oxford and IBH publishing co., New Delhi pp. 9-100.

$$
\begin{aligned}
& \text { تاثير حامض الجلوتاميك والبورون علي نمو وانتاجية العنب الردجلوب }
\end{aligned}
$$

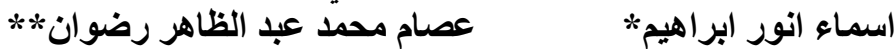

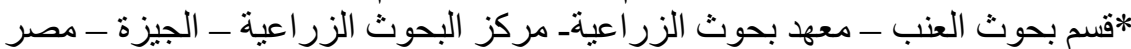

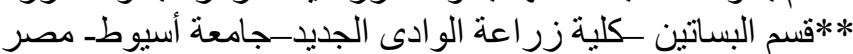

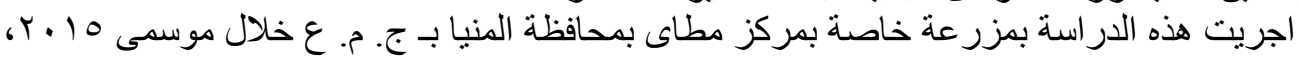

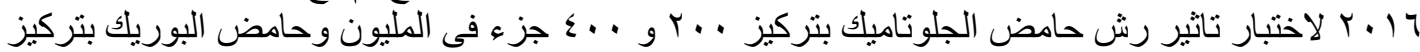

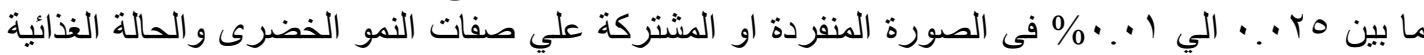

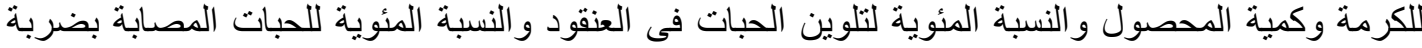

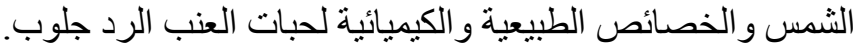

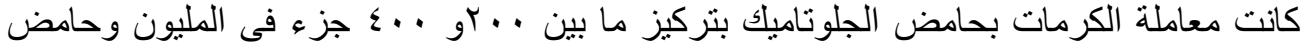

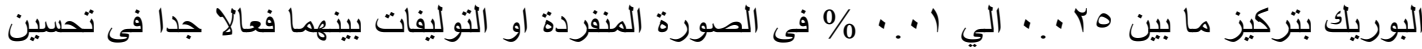

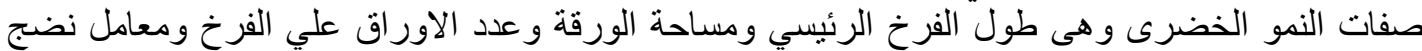

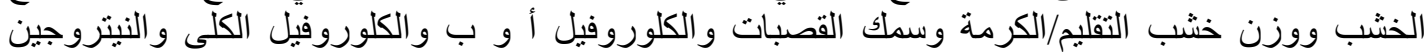

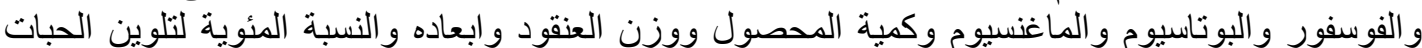

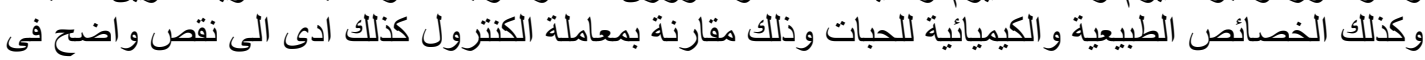
النسبة المئوية للحبات المصابة بضربة المبانة الثمس.

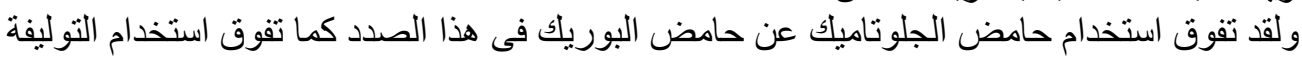

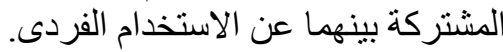

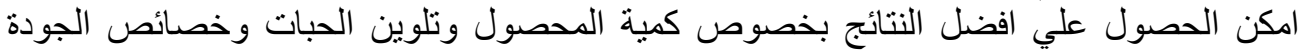

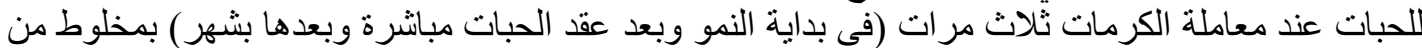

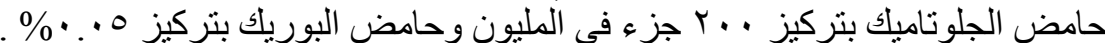

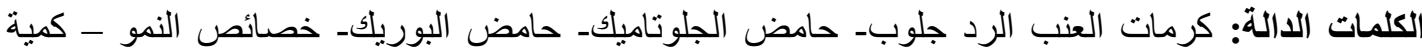

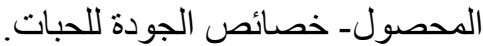

